\title{
Comparative Study of Political Institutions in Developed and Developing Countries Based on institutional Economy
}

\author{
Samad Rasoulzadeh Aghdam
}

Ph.D. candidate of socio-c-economic development, University of Isfahan, Iran.

Samad1356@gmail.com

Behjat Yazdkhasti

Associate professor of sociology, University of Isfahan, Iran. b.yazdkhasti@Itr.ui.ac.ir

Mohammad Sadegh Mahdavi

Professor of sociology, Azad University of Tehran, Science and Research Branch, Tehran. Iran. d_mahdavy@yahoo.com

\section{Doi:10.5901/mjss.2013.v4n2p97}

\section{Abstract:}

From institutional view, development can't occurs in vacuum. Economic maturation and growth in the markets need institutional framework which facilitates the transactions in a regular order. Actors know that made decisions and contracts are supported and executed by the law. Savors, investors, consumers, employers, workers, and risk takers need a framework of rational laws which support their decisions. They need confidence about economic stability which is provided by strong leaders and decision-makers. On the contrary, the lack of ownership rights, laws, and political stability will lead to economic anarchy. This study aims to examine different indicators of political institutions related to economic development, reflecting the differences of developed countries with other regions. It also attempts to investigate whether effective political institutions can provide the grounds for economic development as the good indicators of governance or not. This study uses the data of worldwide governance indicators. The indicators include voice and accountability, political stability and absence of violence, government effectiveness, regulatory quality, rule of law, control of corruption from 1996-2011 in 215 countries of the world. The results show the better status of economically developed countries regarding good governance indicators.

Keywords: Institutional Economy; Political Institutions; Economic Development; Developed Countries; Developing Countries;

\section{Introduction}

Institutionalist approach has exceeded traditional economy. It doesn't equal economy with market. Instead, it defines market as the institutions consisting of sub-sections connected with other institutional groups such as culture, government, rules, ideology, and etc. According to institutionalism, market can't guaranty optimal resource allocation and distribution. This is a structure of institutional organizations and power in the society which allocate the resources. They regard demand and supply mechanisms as the function of power, wealth, and institutional structure, rather than considering goods and service distribution and price as the function of demand and supply mechanism in a conceptual market. The cornerstone of institutional economy lies in the fact that during analyzing economic phenomenon and designing economic policies, social frames, cultural structure, historical identity, and political backgrounds of under-study society shouldn't be ignored. Social life and its sub-structures are not a mechanical phenomenon, identifiable independent from history neglecting social parameters. According to institutionalists, there is no global theory in social sciences and social theories are relative. This relativity denies model application and postulates pattern usage. Pattern is a map drawn on the geography of social, political, and economic life. Since the geographic map of each country differs, 
their social lives are different and don't follow a common model. So, ignoring these maps (pattern), policy-making is impossible. In institutional approach, advance occurs in response to developmental evolution of social, supportive, and business institutions (Wallis and North 1988). So, development extent of the countries depends on the control degree of business risks (including transaction costs, the lack of illegal profit-seeking in economic activities, balanced division of losses, and etc) by the institutions (Klein 1998). Effective institutions decrease information costs, encourage capital formation and its free movement, and price risks (insurances) and provide other cooperative facilities. Spreading these institutions develops industrial and economic development. Nowadays, governments' effectiveness is a determinant in the economic dynamism of the countries. Governments and political institutions can refresh public institutions, enact effective rules, fight with corruption, and be accountable toward people to create proper fields for economic and productive incentives.

For the institutionalists, the type of government system is a major concern. When the government includes more ideas of different groups in the society and is more comprehensive, it will fulfill the needs of different groups better and distributes the resources more fairly. The government is responsible for creating a safe and stable context for encouraging investors. These goals are achievable via predicting investments profit, recognizing investment opportunities and their realization (Hirschman 1988), creating a confident environment for proper risk distribution in investment networks (such as insurance, financial institutes, and investors). In the case of lacking theses institutions, government should take these responsibilities. According to Gerschenkron (1962), government is confined to the innovation of the processes of capital accumulation and active cooperation in it. Polany (2005) asserts that organized and significant intervention of the government facilitates open markets. So, market survival relies on social connections as well as government policies. For an efficient market, a regular and modern government is essential without which exerting the best policies are useless. For example, the effective role of the government in newly-industrialized East Asian countries and controlling political and social disorders along with constructive interactions with specific groups is an important factor in their development (Evans 1997). The results of World Bank investigations (1997) on internal corporations of 69 countries show that weak and pertinacious government institutions add to the problems by their unpredictable and inconsistent behaviors, obstructing market development.

\section{Literature review}

There is no consensus on the identification of institution and everyone defines it based on his thoughts and taste. For example, Cammons refers to institution as any group action controlling personal activities (Medema et al. 2000). Donport introduces institution as any accepted belief, habit or custom of the society. In other definitions, institution is an organized system of social relations guarantying definite and public values and procedures that meet special needs of the society. It is a set of processes that form formal or informal states of economic actors' behaviors, affecting their thoughts and programs (Campbel 1997). As the winner of Nobel Prize and a top institutionalist, North states: institutions are play rules in the society. They are norms made by humans that form mutual relations of them and systematize hidden incentives in human transactions (North 1990). By offering structures for routine life, institutions decrease uncertainty, determining the performance of the economies in long term. In economics, institution for traditional thinkers is a set of habits, rules, and individual actors inside an institutional field. But, for modern thinkers it refers to the main center of analysis and social development as a response to face-to-face problems (Harris et al. 1995, Hadgson 1998).

According to Yefo and Nognet (1995), institutions are a set of created behavioral rules, made by humans for organizing and formation of human interactions, helping them in having expectations from others' actions.

Hall and Tailor (2006), two historical institutionalists, define institutions as the formal and informal methods, current habits, persistent values and contracts in political and economic organizational structure. Levi et al. (1994) state that: institutions are not just a variable beside other variables. Not only they form strategies, but also they set the goals in logical choices. According to Torfing (2001)and historical institutionalists, institutions are formed norms inherited from the past.

In 1960s and 1970s, economists focused on monetary policies in the field of micro economy policies. In late 1980s, as a result of introducing new issues, many experimental studies found a relationship between long-term economic growth rate and political variables and institutional indicators. In these issues, the importance of other aspects of governmental policies and the function of economic, legal, and political institutions is highlighted. At that time, good government and organizational system in development process was first introduced in the report of 1989 of World Bank about Africa (World Bank 1989). Based on that report, such government has received its power and legitimation from 
democratic contracts, based on full differentiation of constitutional and executive powers. That government is efficient, independent, open, and responsive.

Fig 1:The role of institutions in political performance

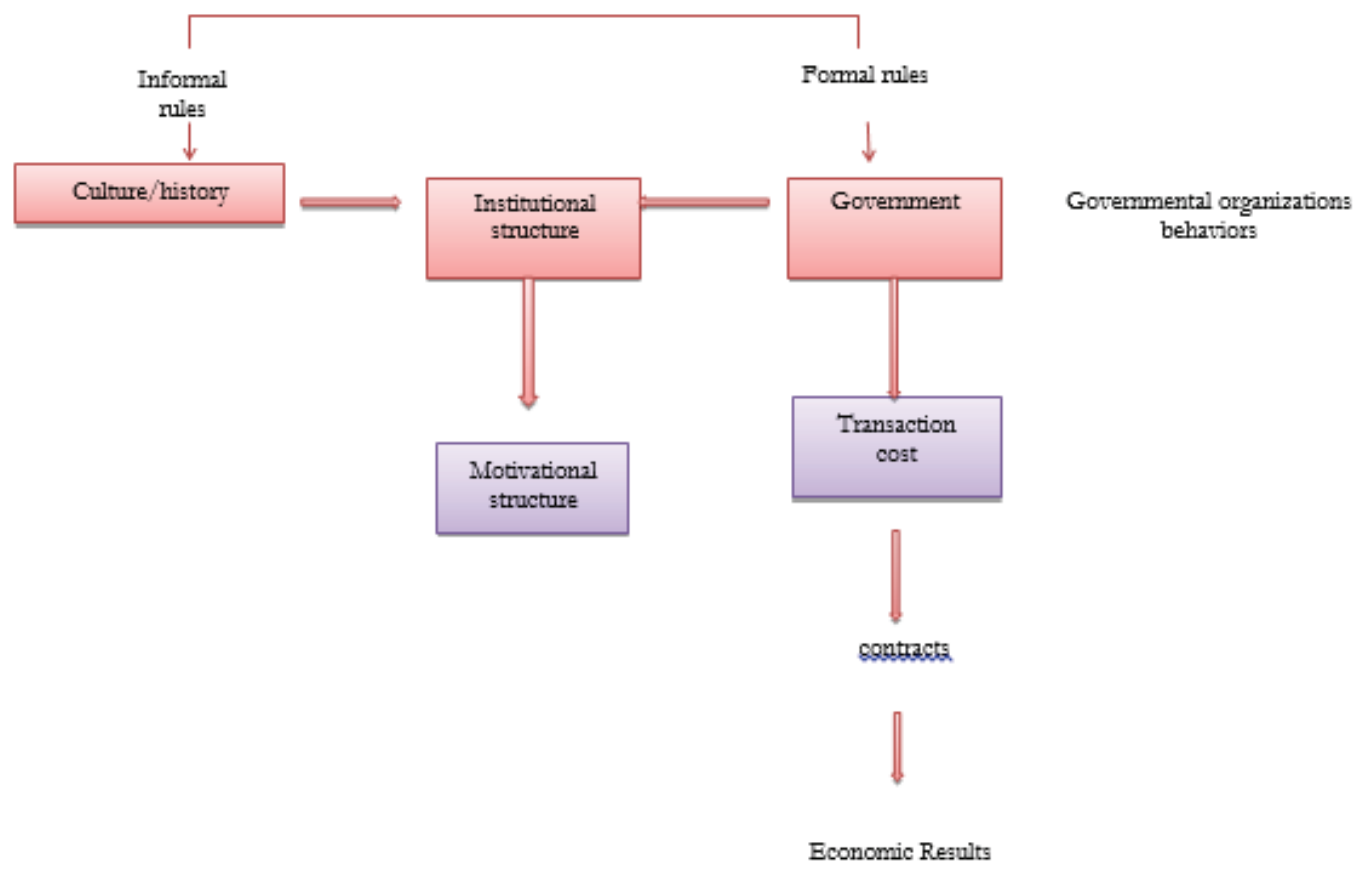

Resource: World Bank report (1977)

Started by the works of Knack and Keefer (1995), the importance of institution-making and constraining government by new institutional economy has been highlighted, dealing with the effects of good institutions on economic growth. Benedsen et al. (2005) identify institutions as the formers of economic environments in which the companies and people act. From institutionalists' attitude, there are many differences in the costs of establishing economic activities and the abilities of investors in yield collection. A major part of these differences results from the differences in governmental policies and the role of the institutions. Factors like excessive governmental rules, price changes, high tax rates, economic instability, business barriers, economic corruption, ownership right violation, and domestic and foreign political unrests, increase investment costs and economic activities. In return, economic and political stability, foreign business development, willingness of institutions to production, development of privatization, omitting governmental exclusion, making the market competitive and efficient increase the expected profitability of the investments and generic activities. In other words, maximization which is a basic assumption of new institutionalists (Furubotn 2005) is set based on formal and informal rules. The cases like what was mentioned are the results of the performance of political, economic, and legal institutions. Direction of an economy toward reformation in the structure of institutions can encourage investment and skills' accumulation, technology transfer, and efficient use of these investments, leading to economic dynamism and constant growth.

Many studies have been done on the relationship between political institutions and economic development since 2000 whose summary is shown in Table 1. 
Table 1. Studies on the relationship between political institutions and economic development

\begin{tabular}{|c|c|c|c|c|c|c|}
\hline Author & $\begin{array}{l}\text { Year of } \\
\text { publicatio } \\
n\end{array}$ & $\begin{array}{l}\text { Main } \\
\text { institutional } \\
\text { data source }\end{array}$ & $\begin{array}{l}\text { Country } \\
\text { coverage }\end{array}$ & $\begin{array}{l}\text { Time } \\
\text { frame }\end{array}$ & $\begin{array}{l}\text { Estimation } \\
\text { type }\end{array}$ & Main result \\
\hline $\begin{array}{l}\text { Chang } \\
\text { and } \\
\text { Calderon }\end{array}$ & 2000 & $\begin{array}{l}\text { BERE, ICRG } \\
\text { ( Institutional } \\
\text { Quality) }\end{array}$ & $35-110$ & $\begin{array}{l}1972- \\
1995\end{array}$ & $\begin{array}{l}\mathrm{PD} \text { (see } \\
\text { Gawecke et } \\
\text { al. 1982) }\end{array}$ & $\begin{array}{l}\text { For poorer countries, } \\
\text { causation runs from } \\
\text { institutions to growth, but } \\
\text { reverse causation also } \\
\text { apparent (for full sample, } \\
\text { causality from growth to } \\
\text { institutions is stronger) }\end{array}$ \\
\hline Wei & $2000 a$ & $\begin{array}{l}\text { Composite } \\
\text { index, derived } \\
\text { from various } \\
\text { sources, } \\
\text { including ICRG, } \\
\text { global } \\
\text { Compitativenes } \\
\text { s Report(1997) } \\
\text { and World } \\
\text { Development } \\
\text { Report(1997) }\end{array}$ & $\begin{array}{l}\text { Country } \\
\text { pairs } \\
\text { source } \\
\text { country } \\
\text { lenders to } \\
\text { host } \\
\text { country } \\
\text { borrowers) } \\
126\end{array}$ & \begin{tabular}{|l}
$1994-$ \\
1996 \\
(average)
\end{tabular} & OLS & $\begin{array}{l}\text { Hypothesis is that higher } \\
\text { corruption means greater } \\
\text { reliance on short -term } \\
\text { foreign borrowing (hot } \\
\text { money) than foreign direct } \\
\text { investment. Find this } \\
\text { results significant and } \\
\text { robust }\end{array}$ \\
\hline $\begin{array}{l}\text { Rauch } \\
\text { and } \\
\text { Evans }\end{array}$ & 2000 & $\begin{array}{l}\text { Own survey on } \\
\text { bureaucratic } \\
\text { structure, filled } \\
\text { out by country } \\
\text { experts }\end{array}$ & 35 & $\begin{array}{l}1970- \\
1990\end{array}$ & OLS & $\begin{array}{l}\text { Bureaucratic } \\
\text { quality(various measures). } \\
\text { Meritocratic recruitment is a } \\
\text { significant determinant for } 2 \\
\text { of } 3 \text { datasets on } \\
\text { bureaucratic quality, but } \\
\text { competitive } \\
\text { salaries, internal promotion } \\
\text { and career stability not } \\
\text { significant }\end{array}$ \\
\hline Ali & 2001 & $\begin{array}{l}\text { Various political } \\
\text { instability } \\
\text { variables, from } \\
\text { Taylor } \\
\text { Hudson (1972, } \\
\text { 1976), Banks } \\
\text { (various). Uses } \\
\text { various fiscal, } \\
\text { monetary and } \\
\text { trade policies } \\
\text { as proxies for } \\
\text { instability, such } \\
\text { as public debt } \\
\text { and budget } \\
\text { deficits }\end{array}$ & 119 & $\begin{array}{l}1970- \\
1995\end{array}$ & OLS & $\begin{array}{l}\text { Traditional measures of } \\
\text { instability not } \\
\text { significant, but volatility of } \\
\text { government } \\
\text { policies is a significant } \\
\text { factor ineconomic growth }\end{array}$ \\
\hline Clarke & 2001 & $\begin{array}{l}\text { ICRG (Risk of } \\
\text { Expropriation, } \\
\text { and Rule of } \\
\text { Low }\end{array}$ & various & $\begin{array}{l}1983- \\
1995\end{array}$ & $\begin{array}{l}\mathrm{PD} \text { (fixed } \\
\text { effects) }\end{array}$ & $\begin{array}{l}\text { better institutional quality is } \\
\text { associated with higher } \\
\text { Research \& Development } \\
\text { expenditure in developing } \\
\text { countries }\end{array}$ \\
\hline
\end{tabular}




\begin{tabular}{|c|c|c|c|c|c|c|}
\hline $\begin{array}{l}\text { Campo } \\
\text { s and } \\
\text { Nugent }\end{array}$ & 2003 & $\begin{array}{l}\text { SPI } \\
\text { (assassinations, } \\
\text { revolutions and } \\
\text { successful } \\
\text { coups) }\end{array}$ & 94 & $\begin{array}{l}1960- \\
1995\end{array}$ & $\begin{array}{l}\text { PD } \\
\text { (Anderson- } \\
\text { Hsiao) }\end{array}$ & $\begin{array}{l}\text { Investment to GDP ratio. } \\
\text { Using Granger } \\
\text { causality, found that SPI } \\
\text { had a ignificant, } \\
\text { positive effect on } \\
\text { investment (higher SPI in } \\
\text { previous period led to } \\
\text { higher investmentin current } \\
\text { period) }\end{array}$ \\
\hline $\begin{array}{l}\text { Lambs } \\
\text { dorff }\end{array}$ & 2003 & $\begin{array}{l}\text { Freedom House } \\
\text { Index of } \\
\text { Civil Liberties } \\
\text { Transparency } \\
\text { International; } \\
\text { ICRG; Freedom } \\
\text { House Political } \\
\text { and Civil } \\
\text { Liberties } \\
\text { (corruption } \\
\text { viewed in terms } \\
\text { of its 'sub- } \\
\text { components' of } \\
\text { (bureaucratic } \\
\text { quality } \\
\text { law and order, } \\
\text { and civil } \\
\text { liberties, among } \\
\text { others) }\end{array}$ & 47 & $\begin{array}{l}195019 \\
77\end{array}$ & OLS/2SLS & $\begin{array}{l}\text { Divided investment } \\
\text { between that from } \\
\text { domestic savings versus } \\
\text { capital inflows from abroad. } \\
\text { Found a significant effects } \\
\text { on capital inflow, but only } \\
\text { through rule of low } \\
\text { variable((bureaucratic } \\
\text { quality, civil liberties and } \\
\text { government stability were } \\
\text { not found tobe important) }\end{array}$ \\
\hline $\begin{array}{l}\text { Dawso } \\
\mathrm{n}\end{array}$ & 2003 & $\begin{array}{l}\text { Economic } \\
\text { Freedom Index } \\
\text { (Gwartney et al. } \\
\text { 1996) }\end{array}$ & Not stated & $\begin{array}{l}1970- \\
2000\end{array}$ & $\begin{array}{l}\text { PD } \\
\text { (Gawecke) }\end{array}$ & $\begin{array}{l}\text { Overall economic freedom } \\
\text { precedes growth,but } \\
\text { individual components } \\
\text { have mixed causality with } \\
\text { growth }\end{array}$ \\
\hline $\begin{array}{l}\text { Glaeser } \\
\text { et al. }\end{array}$ & 2004 & $\begin{array}{l}\text { ICRG, KKZ } \\
\text { and Polity IV }\end{array}$ & various & $\begin{array}{l}1960- \\
2000 \\
\text { Plus } \\
\text { long- } \\
\text { term } \\
\text { growth } \\
(1870- \\
1950)\end{array}$ & OLS/2SLS & $\begin{array}{l}\text { Current institutional } \\
\text { measures do not reflect } \\
\text { 'deep' determinants, and } \\
\text { human capital is a more } \\
\text { persistent and long-term } \\
\text { determinant of growth }\end{array}$ \\
\hline $\begin{array}{l}\text { Gwartn } \\
\text { ey et al. }\end{array}$ & 2004 & $\begin{array}{l}\text { Economic } \\
\text { freedom index }\end{array}$ & 91-99 & $\begin{array}{l}\text { Per } \\
\text { capita } \\
\text { income } \\
\text { in } \\
2000 \text {, } \\
\text { growth } \\
1980- \\
2000\end{array}$ & OLS & $\begin{array}{l}\text { Economic freedom impacts } \\
\text { on both income levels and } \\
\text { growth rates. Also affects } \\
\text { the rate of investment as } \\
\text { well as productivity. Also } \\
\text { some causal } \\
\text { interpretations, that } \\
\text { changes in } \\
\text { economic freedom take 5- } \\
10 \text { years } \\
\text { to impact on income }\end{array}$ \\
\hline
\end{tabular}




\begin{tabular}{|c|c|c|c|c|c|c|}
\hline $\begin{array}{l}\text { Alfaro } \\
\text { et al. }\end{array}$ & 2005 & $\begin{array}{l}\text { ICRG (Settler } \\
\text { mortality used } \\
\text { as instrument }\end{array}$ & $58-98$ & $\begin{array}{l}1970- \\
2000\end{array}$ & OLS/2SLS & $\begin{array}{l}\text { Institutional quality is the } \\
\text { primedeterminant of capital } \\
\text { flows and investmentacross } \\
\text { countries }\end{array}$ \\
\hline $\begin{array}{l}\text { Treism } \\
\text { an }\end{array}$ & 2000 & $\mathrm{TI}$ and $\mathrm{BI}$ & $36-81$ & $\begin{array}{l}1996- \\
1998 \\
\text { forTI, } \\
1980 \text { s } \\
\text { for BI }\end{array}$ & OLS/WLS & $\begin{array}{l}\text { Corruption is associated } \\
\text { with a number offactors, } \\
\text { including trade openness } \\
\text { (measured as ratio of } \\
\text { imports to GDP). } \\
\text { Significant for TI in } 1996 \\
\text { and 1997, but not } 1998 \\
\text { (see Knack and Azfar } \\
2003 \text {, for possible reason } \\
\text { why) }\end{array}$ \\
\hline Wei & $2000 \mathrm{~b}$ & $\begin{array}{l}\text { Business } \\
\text { International } \\
\text { (average 1980- } \\
\text { 1983), } \\
\text { Democracy } \\
\text { dummy; } \\
\text { Transparency } \\
\text { International } \\
\text { (1998) }\end{array}$ & 126 & $\begin{array}{l}(1978- \\
1980) \\
\text { and } \\
(1994- \\
1996)\end{array}$ & OLS & $\begin{array}{l}\text { Countries that are } \\
\text { 'naturally' open (due to } \\
\text { geography or size) have } \\
\text { better institutions, and pay } \\
\text { their civil servants a higher } \\
\text { wage }\end{array}$ \\
\hline Torrez & 2002 & TI, ICRG & Various & $\begin{array}{l}1980- \\
1985 \\
(\mathrm{TI}) \\
1982- \\
92 \\
(\mathrm{ICRG})\end{array}$ & OLS & $\begin{array}{l}\text { Higher corruption (when } \\
\text { using TI) significantly } \\
\text { associated with lower trade } \\
\text { openness (various } \\
\text { definitions). Not significant } \\
\text { when using ICRG }\end{array}$ \\
\hline $\begin{array}{l}\text { Levche } \\
\text { nko }\end{array}$ & 2004 & $\begin{array}{l}\text { KKZ (Rule of } \\
\text { Law) }\end{array}$ & $81-117$ & $\begin{array}{l}1998 \\
\text { (for US } \\
\text { imports } \\
\text { ),variou } \\
\text { s for } \\
\text { other } \\
\text { variabl } \\
\text { es }\end{array}$ & OLS & $\begin{array}{l}\text { Countries with better } \\
\text { institutions capture larger } \\
\text { import shares in industries } \\
\text { that are more 'institutionally } \\
\text { complex'. There is a 'race } \\
\text { to the top' as countries try } \\
\text { to improve their institutions } \\
\text { to capture a greater share } \\
\text { of this trade in more } \\
\text { elaborate goods }\end{array}$ \\
\hline $\begin{array}{l}\text { Rigobo } \\
\mathrm{n} \text { and } \\
\text { Rodrik }\end{array}$ & 2005 & $\begin{array}{l}\text { KKZ Rule of } \\
\text { Law, Knack and } \\
\text { Keefer (ICRG) }\end{array}$ & $\begin{array}{l}\text { North- } \\
\text { south vs } \\
\text { east-west } \\
\text { sample, } \\
\text { and a } \\
\text { colony-not } \\
\text {-colony } \\
\text { sample }\end{array}$ & 86 & $\begin{array}{l}\text { 'Identification } \\
\text { through } \\
\text { Heterosked- } \\
\text { asticity' (IH) }\end{array}$ & $\begin{array}{l}\text { Democracy and the rule of } \\
\text { law are both good for } \\
\text { economic performance. } \\
\text { Trade openness has a } \\
\text { negative impact on income } \\
\text { levels but a positive effect } \\
\text { on rule of law. Higher } \\
\text { income produces greater } \\
\text { openness and better } \\
\text { institutions, but these } \\
\text { effects are not very strong }\end{array}$ \\
\hline
\end{tabular}




\begin{tabular}{|l|l|l|l|l|l|l|}
\hline Breton & 2004 & $\begin{array}{l}\text { 'Bureaucratic } \\
\text { efficiency' from } \\
\text { Mauro (1995), } \\
\text { taken from } \\
\text { Business } \\
\text { International } \\
\text { (1980-1983). } \\
\text { Called this } \\
\text { 'Government } \\
\text { Integrity' }\end{array}$ & & $1960-$ & OLS/2SLS & $\begin{array}{l}\text { Using Mankiw et al. (1992) } \\
\text { as base employed different } \\
\text { specifications of education } \\
\text { variables. The institutional } \\
\text { variable remained } \\
\text { significant in each } \\
\text { regression }\end{array}$ \\
\hline
\end{tabular}

Among significant variables of the quality of political institutions, variables of Kaufman et al. (2010) are used in this study. This indicator shows political information of 215 countries of the world in 6 aspects of voice and accountability, political stability and the absence of violence, government effectiveness, regulatory quality, rule of law, and control of corruption.

Instability of political systems and internal and external threats increase the costs of investment and economic activities, decreasing the incentives for generic and especially long-term activities. The indicator of political stability shows the extent of vulnerability of political systems against threats and illegal actions. Used criteria for preparing this indicator include tribal, cultural, and religious conflicts, political unrests, violent strikes, urban rebellions, political assassinations, kidnapping, coup d'états, and international tensions. The range of changes in this indicator is -2.5-+2.5. The closer this value to the larger limit, the higher the political stability will be. Government effectiveness indicator measures the ability of the government in micro-economic policy-makings. In identifying this indicator, the issues such as governmental efficiency in maintaining national substructures, tax gathering, budget assignment, response to economic issues and natural disasters, monitoring economic and social revolutions, bureaucracy quality, the ability of the government to execute announced programs, preservation of its status, continuous management during crisis, and political/economic consistency. The range of changes in this indicator is $-2.5-+2.5$.

Rule of law indicator shows the performance of legal system and law authority extent in every country. In that indicator, the variables such as legal system's independence versus the government and other activists, speed and neutrality in judgment process, regulation settlement, commitment to the contracts by the government, public, and private sections, ownership rights, black market, violent crimes, kidnapping foreigners, money laundry, and organized crime play roles. The range of changes in this indicator is $-2.5-+2.5$.

Organizational and executive corruption among government staff can negatively impact the trend of generic activities increasing transaction costs. Used factors in measuring the control of corruption indicator include corruption control in government, privilege donation to the relatives and supporters of the government, diversion from investment, generalizing extra payments for certificating exports and imports, public facilities, financial credit requests, tax payments, abusing authority in legal orders and law execution.

Another indicator of Kaufman et al(2010) is regulations and instructions' quality which includes the variables like exportimport constraints, fair competition in economic regions, price and wage control, discriminating tariffs, governmental intervention, business rules, foreign investments, banking, donating citizenship to the foreigners, regulations conformity with legal system of other countries, and the existence of needed rules of the occupations.

Responsiveness indicator refers to citizens' liberty for cooperation in government selection, liberty of speech and pen. Many studies have been done on the relationship between democracy and economic performance either negative or positive. Barro (1996) estimated this relation in reverse $U$ form. He states that in the presence of a full dictatorship in a country, improvement of political rights leads to the limitations on the authority of the dictator and more growth. But in the countries with intermediate levels of political laws, increasing political rights will deteriorate economic growth for intensifying people and officials 'attention to the programs of social welfare and redistribution of different forms.

\section{Research methodology}

This study aims to use comparative method and secondary analysis technique. For this purpose, the information of 215 countries was gathered from 1996-2011 for 6 indicators of Kaufman et al. (2010).To compare these indicators, the countries were divided into the countries with developed economy, developing Asian countries, middle east and north African countries, Latin American and Caribbean countries, and African desert countries. This study aims to compare the 
average scores of government indicators in 5 regions whose names are shown in table 2 differentiating each region. The basis of classifying these countries was the report of international money fund (2012). In this study, one-way variance analysis was used to show the mean differences of the indicators in 5 geographic-economic regions. The following LSD test was used to show the difference of the regions with developed economy or other regions of the world. To understand the relationship of 6 aspects of governmental indicators, Pearson correlation coefficient and distribution were used. Their results are shown as correlation matrix and distribution figures. In the present study calculations were done based on the mean of percentile rank of the indicators for 16 years (1996-2011). This mean has a variation range of 0 to 100 . The closer the values to higher numbers, the better the rank of the countries become.

Table 2: The list of the under-study countries

\begin{tabular}{|l|l|}
\hline $\begin{array}{l}\text { Sub-Saharan } \\
\text { Africa }\end{array}$ & $\begin{array}{l}\text { Angola, Benin, Botswana, Burkina Faso, Burundi, Cameroon, Central Africa, Chad, Comoro } \\
\text { Islands,Congo,'Brazzav, Djibouti,Equatorial Eritrea and Et,Gabon,Gambia,Ghana,Guinea, } \\
\text { GuineaBissau,Haïti,Kenya,Lesotho,Liberia,Libya,Madagascar,Malawi,Mali,Mauritania,Mauritius } \\
\text {,Mozambique,Namibia,Niger,Nigeria, Rwanda, Senegal, Seychelles, Sierra Leone, Somalia, } \\
\text { South Africa, Swaziland, Tanzania, Togo, Uganda,Zambia, Zimbabwe }\end{array}$ \\
\hline $\begin{array}{l}\text { Latin America } \\
\text { and } \\
\text { caraibian }\end{array}$ & $\begin{array}{l}\text { Argentina, Bolivia, Brazil, Chile, Colombia, Costa Rica, Cuba, Dominican Repu, Ecuador, El } \\
\text { Salvador,Guatemala,Honduras,Jamaica,Mexico,Nicaragua,Panama,Paraguay,Peru,Uruguay, } \\
\text { Venezuela }\end{array}$ \\
\hline $\begin{array}{l}\text { Middle East and } \\
\text { North Africa }\end{array}$ & $\begin{array}{l}\text { Algeria,Bahrain,Egypt,Iran,Iraq,Jordan,Kuwait,Lebanon,Morocco,Oman,Qatar,Saudi Arabia, } \\
\text { Sudan, Syria, Tunisia, United Arabian, Yemen }\end{array}$ \\
\hline $\begin{array}{l}\text { Developing } \\
\text { Asia }\end{array}$ & $\begin{array}{l}\text { Afghanistan,Bangladesh,Cambodia,India,Indonesia,Laos,Malaysia,Mongolia,Nepal,North } \\
\text { Korea, Norway, Pakistan, Philippines, Sri Lanka, Thailand, Vietnam }\end{array}$ \\
\hline $\begin{array}{l}\text { Advanced } \\
\text { economies }\end{array}$ & $\begin{array}{l}\text { Australia,Austria,Belgium,Canada,Denmark,Finland,France,Germany,Hong Kong, Israel, Italy, } \\
\text { Japan, Netherlands, New Zealand, Singapore, South Korea, Sweden, Taiwan, Turkey, }\end{array}$ \\
\hline
\end{tabular}

\section{Findings and discussion}

In this study, the comparison of governmental indicators was done in 5 regions of the world. In Table 3, the frequency and the mean of percentile rank of each indicator is mentioned for different regions.

Table 3: Mean comparison of government indicator in 5 regions of the world (1996-2011)

\begin{tabular}{|c|c|c|c|c|c|c|}
\hline & & $z$ & $\begin{array}{l}\overline{\mathbb{N}} \\
\stackrel{\mathbb{N}}{\Sigma}\end{array}$ & क्ष & & $\frac{.0}{\infty}$ \\
\hline \multirow[t]{5}{*}{ Voice and Accountability } & Advanced economies & 21 & 83.01 & 17.68 & \multirow[t]{5}{*}{33.226} & \multirow[t]{5}{*}{.000} \\
\hline & Developing Asia & 16 & 34.87 & 24.58 & & \\
\hline & Middle East and North Africa & 17 & 20.44 & 10.23 & & \\
\hline & Latin America and the Caraibian & 20 & 50.23 & 18.02 & & \\
\hline & Sub-Saharan Africa & 44 & 32.05 & 21.05 & & \\
\hline \multirow[t]{5}{*}{ Political Stability } & Advanced economies & 21 & 72.67 & 22.57 & \multirow[t]{5}{*}{11.811} & \multirow[t]{5}{*}{.000} \\
\hline & Developing Asia & 16 & 30.74 & 26.26 & & \\
\hline & Middle East and North Africa & 17 & 35.50 & 25.50 & & \\
\hline & Latin America and the Caraibian & 20 & 37.15 & 18.18 & & \\
\hline & Sub-Saharan Africa & 44 & 35.40 & 22.77 & & \\
\hline \multirow[t]{3}{*}{ Government Effectiveness } & Advanced economies & 21 & 90.00 & 9.77 & \multirow[t]{3}{*}{31.476} & \multirow[t]{3}{*}{.000} \\
\hline & Developing Asia & 16 & 40.78 & 25.88 & & \\
\hline & Middle East and North Africa & 17 & 45.60 & 22.83 & & \\
\hline
\end{tabular}




\begin{tabular}{|c|c|c|c|c|c|c|}
\hline & Latin America and the Caraibian & 20 & 45.41 & 18.60 & & \\
\hline & Sub-Saharan Africa & 44 & 28.38 & 22.75 & & \\
\hline \multirow[t]{5}{*}{ Rgulatory Quality } & Advanced economies & 21 & 89.26 & 10.24 & \multirow[t]{5}{*}{32.423} & \multirow[t]{5}{*}{.000} \\
\hline & Developing Asia & 16 & 37.56 & 23.65 & & \\
\hline & Middle East and North Africa & 17 & 41.99 & 23.16 & & \\
\hline & Latin America and the Caraibian & 20 & 48.39 & 20.37 & & \\
\hline & Sub-Saharan Africa & 44 & 30.00 & 20.69 & & \\
\hline \multirow[t]{5}{*}{ Rule of Law } & Advanced economies & 21 & 88.41 & 11.65 & \multirow[t]{5}{*}{30.390} & \multirow[t]{5}{*}{.000} \\
\hline & Developing Asia & 16 & 38.10 & 24.63 & & \\
\hline & Middle East and North Africa & 17 & 44.46 & 22.71 & & \\
\hline & Latin America and the Caraibian & 20 & 35.45 & 19.21 & & \\
\hline & Sub-Saharan Africa & 44 & 29.78 & 22.39 & & \\
\hline \multirow[t]{5}{*}{ Control of Corruption } & Advanced economies & 21 & 88.22 & 12.90 & \multirow[t]{5}{*}{25.741} & \multirow[t]{5}{*}{.000} \\
\hline & Developing Asia & 16 & 32.65 & 24.61 & & \\
\hline & Middle East and North Africa & 17 & 45.53 & 24.25 & & \\
\hline & Latin America and the Caraibian & 20 & 44.08 & 21.51 & & \\
\hline & Sub-Saharan Africa & 44 & 32.25 & 23.03 & & \\
\hline
\end{tabular}

The results of Table 3 show that the mean of percentile rank of government accountability indicator is significantly different in 5 geographic- economic regions of the world ( $F=33.226$, sig $=.000)$. The maximum mean belongs to advanced economy (Mean=83.01) and the minimum mean belongs to North Africa and Middle East (Mean=20.44). About the indicator of political stability, testing mean difference shows significant difference ( $F=11.811$, sig=.000). The maximum political stability belonged to the countries with advanced economy (Mean=72.67) and the minimum stability belonged to developing countries of Asia (Mean=83.01). Regarding the indicator of government effectiveness, the results show significant difference in the mean of efficiency in different regions of the world $(F=31.226$, sig=.000). The maximum mean belongs to advanced economy (Mean=90.00) and the minimum mean belongs to the countries of Saharan Africa (Mean=28.38). The mean of regulatory quality indicator is significantly different in different countries $(F=32.423$, sig=.000). The maximum mean belongs to advanced economy (Mean=89.26) and the minimum mean belongs to the countries of Saharan Africa (Mean=30.00).

In the case of rule of law, a significant difference is observed in different countries ( $F=32.423, s i g=.000)$. The maximum mean belongs to the countries with advanced economy (Mean=88.46) and the minimum mean belongs to the countries of Saharan Africa (Mean=29.78). There is a significant difference in different countries about the control of corruption indicator $(\mathrm{F}=25.741$, sig=.000). The maximum mean belongs to the countries with advanced economy (Mean=88.22) and the minimum mean belongs to the countries of Saharan Africa (Mean=32.65) and developing Asian countries. Fig. 2 shows the means of indicators in different regions in the framework of a histogram. 
Fig 2: The means of percentile rank of government indicators in 5 regions

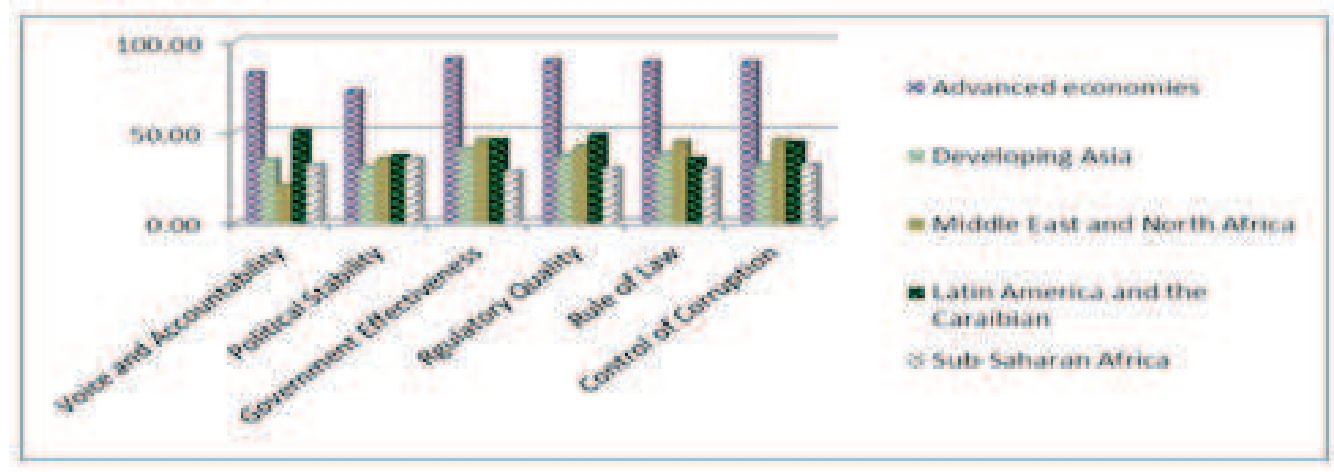

In testing means, a significant difference was observed among different countries in the case of government indicators. LSD tests show that the means of the countries with advanced economy are significantly different with other regions. This can help us in understanding this point that political institutions can create a proper space for economic development.

Table 4: LSD tests results for the means of developed countries and other regions

\begin{tabular}{|c|c|c|c|c|c|c|}
\hline & 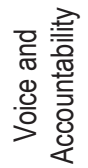 & 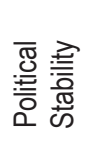 & 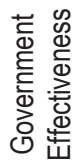 & 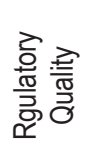 & 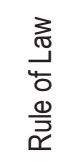 & $\begin{array}{l}\text { 흥 음 } \\
\text { 을 } \\
\text { 음 }\end{array}$ \\
\hline & 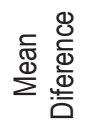 & 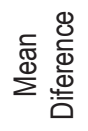 & 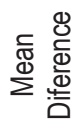 & 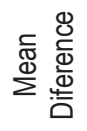 & 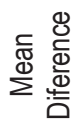 & 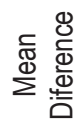 \\
\hline Developing Asia & 48.13 & 41.93 & 49.21 & 51.69 & 50.30 & 55.57 \\
\hline sig & .000 & .000 & .000 & .000 & .000 & .000 \\
\hline Middle East and North Africa & 62.56 & 37.17 & 44.39 & 47.26 & 43.94 & 42.69 \\
\hline sig & .000 & .000 & .000 & .000 & .000 & .000 \\
\hline Latin America and the Caraibian & 32.77 & 35.52 & 44.58 & 40.86 & 52.96 & 44.13 \\
\hline sig & .000 & .000 & .000 & .000 & .000 & .000 \\
\hline Sub-Saharan Africa & 50.95 & 37.27 & 61.61 & 59.25 & 58.63 & 55.97 \\
\hline sig & .000 & .000 & .000 & .000 & .000 & .000 \\
\hline
\end{tabular}

As seen in Table. 4, the means of percentile rank of responsiveness indicator in developed countries is 45.13 higher than the means of developing Asian countries. This mean difference in Middle East and North African countries is higher and 62.56. The minimum difference of developed countries about the indicator of responsiveness belongs to Latin American and Caribbean countries with the significant value of 32.77. The difference of developed countries with African desert countries is 50.95. This difference is in the next rank after Middle East and North African countries. All the differences of responsiveness indicator means are significantly different. About other indicators as seen in Table 4, there are significant differences among developed and other countries. There was a rational and statistical correlation between the indicators. Correlation matrix and distribution figures of the government indicators show a linear and positive correlation among indicators which are significantly significant. 
Fig 3: Correlation matrix of government indicators

\begin{tabular}{l|llllll}
$r$ & VA & PS & GE & RQ & RL & CC \\
\hline VA & 1.000 & & & & & \\
PS & 0.704 & 1.000 & & & & \\
GE & 0.829 & 0.769 & 1.000 & & & \\
RQ & 0.856 & 0.738 & 0.953 & 1.000 & & \\
RL & 0.824 & 0.831 & 0.959 & 0.931 & 1.000 & 1.000 \\
CC & 0.797 & 0.822 & 0.949 & 0.906 & 0.954 &
\end{tabular}

$V A=$ Voice and accountability, $P S=$ Political Stability, GE $=$ Government Effectiveness, $R Q=$ Regulatory Quality, RL= Rule of Law, CC= Control of Corruption

Above-sited matrix shows that all government indicators have strong correlations. It shows the importance of each indicator in good governance and healthy political system for reaching development. Such strong and linear correlations can be observed in Fig 4.

Fig 4: Correlation coefficients of government indicators
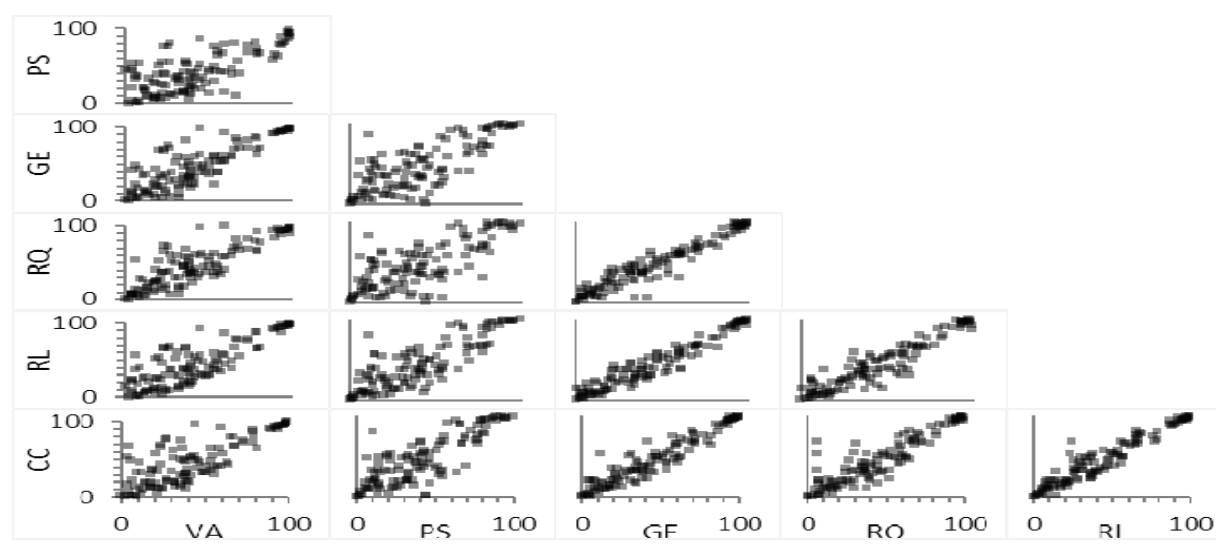

\section{Concluding remarks}

Using government indicators of Kaufman et al. (2010), developed, developing, and under- developed countries were compared. This study examines the difference of government indicators in different countries which is regarded as important in economic development of the society from the view of economic institutionalists. The results showed that political factors such as government accountability, political stability, government effectiveness, regulatory quality, rule of law, and control of corruption are significantly more in developed countries. According to institutionalists, such conditions are necessary for creating a good culture of economic development, decreasing transaction costs. In such context, the possibility of investment in production and industry is provided based on the theory of rational selection. Based on the results, to create necessary conditions for economic development, correction of political structures and efficiency improvement can play an important role. The results of this study can help developing countries or the countries at the start of this road to regard this point that for economic development, only economic conditions such as capital, and savings are not enough. The institutional, cultural, and political conditions are also important in creating incentives for investors, businessmen, and craftsmen.

\section{References}

Barro, R. J. (1999). Determinants of democracy. Journal of Political economy,107(S6), 158-183. 
Bennedsen, M., Malchow-Møller, N., \& Vinten, F. (2005). Institutions and Growth—A Literature Survey. Report prepared for the Danish International Development Agency, Centre for Economic and Business Research, 3.

Campbell, J. L. (1997). Mechanisms of evolutionary change in economic governance: interaction, interpretation and bricolage. Evolutionary economics and path dependence, 10-32.

Chhibber, A., Commander, S., Evans, A., Fuhr, H., Kane, C., Leechor, C., ... \& Weder, B. (1997). The State in a Changing World. World Development Report, 1997. Oxford University Press, Inc., 2001 Evans Rd., Cary, NC 27513.

Evans, P. (1997). The state as problem and solution: Predation, embedded autonomy and structural change. Nova srpska politička misao, 4(1-2), 75-98.

Furubotn, E. G., \& Richter, R. (2005). Institutions and economic theory: The contribution of the new institutional economics. University of Michigan Press.

Gerschenkron, A. (1962). Economic backwardness in historical perspective.Economic backwardness in historical perspective.

Hall, P. A., \& Taylor, R. C. (2006). Political Science and the Three New Institutionalisms*. Political studies, 44(5), 936-957.

Harriss, J. (1995). The new institutional economics and Third World development. Routledge.

Hirschman, A. O. (1988). The strategy of economic development (No. 44). Westview Press.

Hodgson, G. M. (1998). The approach of institutional economics. Journal of Economic literature, 166-192.

International Munetary Fund(IMF). (2012). World Economic Outlook:Coping with High Debt and Sluggish Growth. Washington,D.C:International Munetary Fund.

Jaggers, K., \& Gurr, T. R. (1995). Tracking democracy's third wave with the Polity III data. Journal of Peace Research, 32(4), 469-482.

Kaufmann, D., Kraay, A., \& Mastruzzi, M. (2010). The worldwide governance indicators: methodology and analytical issues. World Bank Policy Research Working Paper, (5430).

Klein, P. (1998). New institutional economics. Available at SSRN 115811.

Knack, S., \& Keefer, P. (1995). Institutions and economic performance: cross-country tests using alternative institutional measures. Economics \& Politics,7(3), 207-227.

Leftwich, A. (1994). Governance, the State and the Politics of Development.Development and change, 25(2), 363-386.

Levy, B., \& Spiller, P. T. (1994). Institutional Foundations of Regulatory Commitment: A Comparative Analysis of Telecommunications Regulation, The.JL Econ. \& Org., 10, 201.

Lipton, M. (1991). Market relaxation and agricultural development. States or Markets, 27.

Medema, S. G., Mercuro, N., \& Samuels, W. J. (2000). Institutional law and economics. The History and Methodology of Law and Economics, 1, 418-55.

North, D. C. (1990). Institutions, institutional change and economic performance. Cambridge university press.

Polanyi, K. (2005). The great transformation: The political and economic origins of our time. Recording for the Blind \& Dyslexic.

Torfing, J. (2001). Path-Dependent Danish Welfare Reforms: The Contribution of the New Institutionalisms to Understanding Evolutionary Change. Scandinavian Political Studies, 24(4).

World Bank. (1989). sub-saharan Africa:from crisis to sustainable growth,Washington,D.C:The World Bank.

Yifu Lin, J., \& Nugent, J. B. (1995). Institutions and economic development.Handbook of development economics, 3, $2301-2370$.

Wallis, J., \& North, D. C. (1988). Should transaction costs be subtracted from gross national product?. The Journal of Economic History, 48(3), 651-654.

Williams, A., \& Siddique, A. (2008). The use (and abuse) of governance indicators in economics: a review. Economics of Governance, $9(2), 131-175$. 